\title{
Removal of nickel from aqueous solutions using Saudi activated bentonite
}

\author{
S. S. Al-Shahrani \\ Department of Chemical Engineering and Material Science, \\ King Abdulaziz University, Saudi Arabia
}

\begin{abstract}
This research project investigates the application of Saudi activated clay (bentonite) to remove nickel from aqueous solutions. The removal characteristics of nickel ions from aqueous solution using Saudi activated bentonite were investigated under various operating variables like shaking time, solution $\mathrm{pH}$, clay dosage and initial metal concentration. The results showed that the sorption of nickel ions on Saudi activated clay was relatively fast and the equilibrium was reached after $40 \mathrm{~min}$. They also showed that increasing the initial nickel concentration decreased nickel removal percentage due to the saturation of clay with nickel ions. Furthermore, the adsorption of nickel increases from 70 to $100 \%$ with an increase in solution $\mathrm{pH}$ from 2.0 to 9.0 . The adsorption isotherm data were well fitted with both the linearized Langmuir and Freundlich models. Nickel adsorption onto Saudi activated bentonite was well represented by the pseudo-second-order kinetic model.

Keywords: removal of nickel, Saudi bentonite, adsorption of nickel, heavy metals removal, adsorption isotherm, adsorption kinetic.
\end{abstract}

\section{Introduction}

Effluent wastewaters from processes such as electroplating, metal finishing, metallurgical, chemical manufacturing and battery manufacturing industries contain toxic substances, metal acids, alkalis, and other substances. Removal of heavy metals such as nickel from aqueous solutions is necessary because of the frequent appearance of these metals in waste streams. This problem has received considerable attention in recent years due primarily to concern that those heavy metals in the waste streams can be readily adsorbed by marine animals and 
directly enter the human food chains, thus presenting a high health risk to consumers $[1,2]$. Nickel compounds are important in modern industry and are used in electroplating, electroforming, and for production of nickel-cadmium batteries and electronic equipment. Nickel alloys, like stainless steel, are used in the production of tools, machinery, armaments, and appliances. They are also used to cast coins, and to produce jewellery and medical prostheses. As the result of accelerated consumption of nickel-containing products nickel compounds are released to the environment at all stages of production and utilization. Their accumulation in the environment may represent a serious hazard to human health. Among the known health related effects of nickel are skin allergies, lung fibrosis, variable degrees of kidney and cardiovascular system poisoning and stimulation of neoplastic transformation [3, 4]. Adsorption of nickel ions by clay has been the subject of several recent studies [5-9]. It was found that the adsorption of nickel from aqueous solution depends on contact time, amount of adsorbent, solution $\mathrm{pH}$ and Nickel concentration.

The main objective of this study is to investigate the feasibility of using Saudi activated clay (bentonite) to remove nickel from aqueous solutions. The choice of this material is based on its low cost, considering its abundance in Khulays bentonite deposit, $95 \mathrm{~km}$ north of Jeddah.

\section{Materials and methods}

\subsection{Preparation of Saudi activated bentonite}

Saudi raw clay (bentonite) used in this study was collected from Khulays bentonite deposit, $95 \mathrm{~km}$ north of Jeddah. It was not active in its natural state. In order to modify its adsorptive property, natural bentonite was activated using sulfuric acid leaching. The experimental set up and chemical treatment method with $\mathrm{H}_{2} \mathrm{SO}_{4}$ which was carried out in this study are similar to what have been described previously [10]. Table 1 shows the chemical composition of Saudi Activated bentonite.

Table 1: Chemical composition of and Saudi activated bentonite [10].

\begin{tabular}{cc}
\hline Compound & Chemical composition (\%) \\
\hline $\mathrm{SiO}_{2}$ & 66.2 \\
$\mathrm{Al}_{2} \mathrm{O}_{3}$ & 11.71 \\
$\mathrm{Fe}_{2} \mathrm{O}_{2}$ & 3.0 \\
$\mathrm{TiO} 2$ & 1.5 \\
$\mathrm{MgO}$ & 0.73 \\
$\mathrm{CaO}$ & $<0.05$ \\
$\mathrm{~K}_{2} \mathrm{O}$ & 0.48 \\
$\mathrm{Na}_{2} \mathrm{O}$ & 0.12 \\
$\mathrm{MnO} \mathrm{O}_{3}$ & 0.05 \\
$\mathrm{P}_{2} \mathrm{O}_{5}$ & $<0.05$ \\
L.O.I. $\left(1000^{\circ} \mathrm{C}\right)$ & $<0.05$ \\
\end{tabular}


The acid treatment was conducted using a Pyrex glass batch reactor with boiler-reflux condenser and a magnetic stirrer/hot plate. Acid activation was done using the optimum operating variables such as, $15 \%$ by weight acid concentration, the temperature of boiling, 90 minutes reaction time, moderate mixing, grain size of -200 mesh $(74 \mu \mathrm{m})$ and water to clay ratio of $5: 1$.

\subsection{Adsorption process}

Adsorption tests were made by batch technique at room temperature $\left(25^{\circ} \mathrm{C}\right)$. Stock solution $(1000 \mathrm{mg} / \mathrm{L})$ of nickel is prepared by dissolving the appropriate amounts of analytical reagent grade $\mathrm{Ni}\left(\mathrm{NO}_{3}\right)_{2} \cdot 6 \mathrm{H}_{2} \mathrm{O}$, in distilled water. The stock solutions were diluted as required to obtain standard solutions containing 20-100 $\mathrm{mg} / \mathrm{L}$ of a required heavy metal. A sample of $50 \mathrm{ml}$ of the diluted nickel solution was added to a group of $100 \mathrm{ml}$ conical flasks. Saudi activated bentonite sample in the range of $0.125-1.25 \mathrm{~g}$ was added to each flask under continues mixing using Horizontal Shaker (JULABO SW 22). $\mathrm{pH}$ adjustments was carried out using $1 \mathrm{~N} \mathrm{HCl}$ and $1 \mathrm{~N} \mathrm{NaOH} .200$ rpm shaking was applied in the shaker. Afterward, samples were taken out from the shaker at regular contact time intervals and the clay was separated by filtering. The filtrate was analyzed for nickel concentration by atomic absorption spectrophotometer (AAS). The effects of several factors such as $\mathrm{pH}$, concentration of solution, clay mass and contact time on nickel removal efficiency were investigated.

\section{Results and discussion}

\subsection{Effect of contact time}

Nickel adsorption was studied by varying the contact time between the adsorbate and adsorbent in the range 1-60 min. Adsorption of nickel at different contact time was studied for initial nickel concentration ranging from 20 to $100 \mathrm{ppm}$, while the dose of clay sample was $0.5 \mathrm{~g} / 50 \mathrm{ml}$ and the solution $\mathrm{pH}$ was kept unchanged at 3.2. The data showed that the sorption of nickel ions on Saudi activated bentonite was relatively fast where the equilibrium was reached after 40 min (Figure 1). The adsorption process is fast at the beginning of the reaction due to the adsorption of nickel on the surface sites of clay. The results show that shaking the mixture of different initial concentration for 40 minutes was sufficient to reach equilibrium. They are also show that increasing the initial nickel concentration decreased nickel removal percentage due to the saturation of clay with nickel ions. Saudi activated bentonite removal efficiency needs to be increased by increasing solution $\mathrm{pH}$ about 7 to avoid the nickel hydroxides precipitation region which it is start at the $\mathrm{pH}$ of 8 [11].

\subsection{Effect of pH}

Solution $\mathrm{pH}$ is an important variable which controls the adsorption of the heavy metal from aqueous solution. The effect of $\mathrm{pH}$ on the removal of nickel ions by Saudi activated bentonite was investigated. The adsorption of nickel was studied 


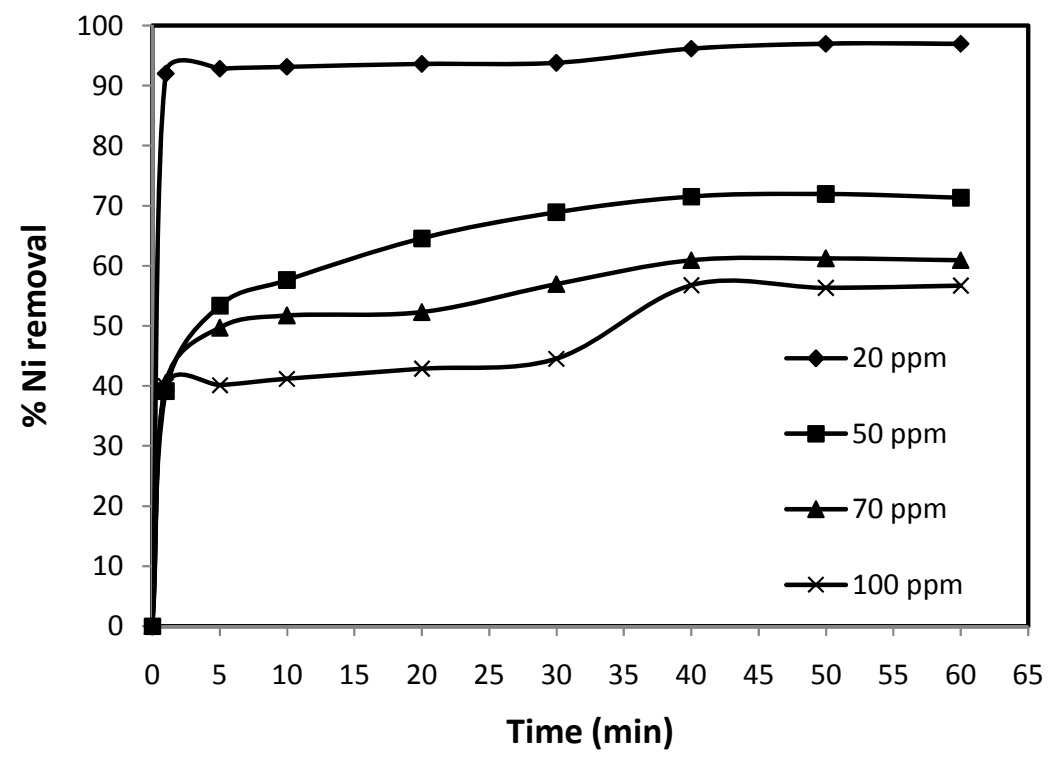

Figure 1: Effect of shaking time on the removal of nickel by Saudi activated bentonite. Initial metal concentration varies between 20 and $100 \mathrm{mg} / \mathrm{L}$, clay dosage: $0.5 \mathrm{~g} / 50 \mathrm{~mL}, \mathrm{pH}=3.2$.

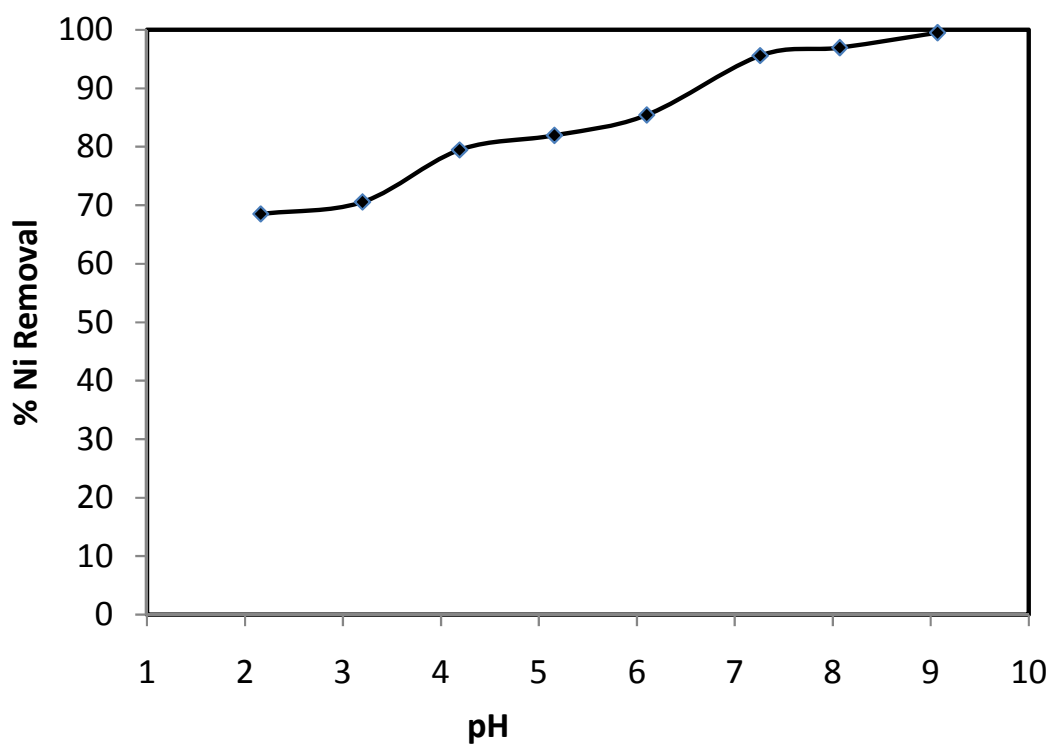

Figure 2: Effect of $\mathrm{pH}$ on the removal of nickel by Saudi activated Bentonite. Initial nickel concentrations $100 \mathrm{mg} / \mathrm{L}$, clay dosage: $0.5 \mathrm{~g} / 50 \mathrm{ml}$, contact time: $40 \mathrm{~min}$. 
in the $\mathrm{pH}$ range 2-9 with a constant clay amount of $0.5 \mathrm{~g} / 50 \mathrm{ml}$ of nickel solution, shaking time of $40 \mathrm{~min}$ and nickel concentration of $50 \mathrm{ppm}$. The results presented in Figure 2 show that the adsorption of nickel increases from 70 to $100 \%$ with an increase in solution $\mathrm{pH}$ from 2.0 to 9.0 .

The effect of initial $\mathrm{pH}$ on nickel removal may be explained as mention before [11], where in the acidic conditions, both adsorbent and adsorbate are positively charged $\left(\mathrm{M}^{2+}\right.$ and $\left.\mathrm{H}^{+}\right)$and therefore, the net interaction is that of electrostatic repulsion. In addition, the $\mathrm{H}^{+}$ions present in higher concentration in the aqueous medium compete with the positively charged $\mathrm{Ni}^{2+}$ ions for the surface adsorbing sites, resulting in a decrease in the removal of nickel.

\subsection{Effect of clay dosage}

The effect of the amount of Saudi activated bentonite on nickel removal was investigated at a constant value of initial metal concentration (100 ppm), clay dosage $(0.05-1.25 \mathrm{~g} / 50 \mathrm{ml})$, contact time $(40 \mathrm{~min}), \mathrm{pH}=7$ and temperature $\left(25^{\circ} \mathrm{C}\right)$. As shown in Figure 3, the removal of nickel increased gradually from $16 \%$ at $0.05 \mathrm{~g} / 50 \mathrm{ml}$ up to $94 \%$ at $1.25 \mathrm{~g} / 50 \mathrm{ml}$. However, this result was expected since as the dose of adsorbent increases, the number of adsorbent sites increases. These amounts attach more ions to their surfaces [12]. Similar results were reported where many types of materials were used as adsorbents [13].

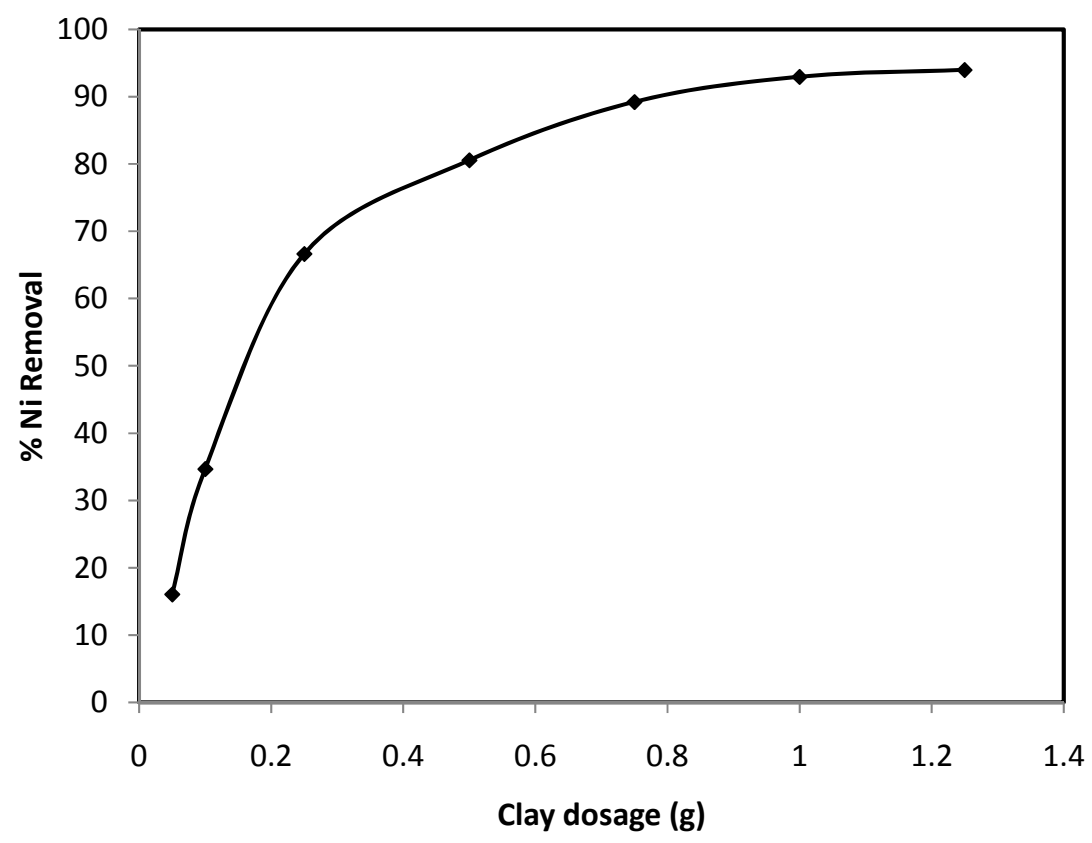

Figure 3: Effect of clay dosage on the removal of nickel by Saudi activated bentonite. Initial nickel concentrations $50 \mathrm{mg} / \mathrm{L}, \mathrm{pH}=7$, contact time: 40 minutes. 


\subsection{Adsorption isotherm}

The adsorption isotherm for nickel was studied using initial concentrations of metal at $100 \mathrm{ppm}, \mathrm{pH}=7$, temperature at $25^{\circ} \mathrm{C}$ and amount of clay dosage (0.05$1.25 \mathrm{~g} / 50 \mathrm{ml})$. The data obtained were fitted to the Langmuir [14] and Freundlich [15] isotherms. These models were tested to determine the maximal capacity of nickel removal using Saudi activated bentonite. The quality of the isotherm fit to the Langmuir equation, in the linear form is written as:

$$
\frac{C_{e}}{q_{e}}=\frac{1}{b q_{\max }}+\frac{C_{e}}{q_{\max }}
$$

where $\mathrm{C}_{\mathrm{e}}$ is the equilibrium concentration of metal ions $(\mathrm{mg} / \mathrm{l}), \mathrm{q}_{\mathrm{e}}$ is the amount of metal ions adsorbed per unit weight of adsorbent ( $\mathrm{mg} / \mathrm{g}$ bentonite), $\mathrm{q}_{\max }$ is the maximum adsorption capacity $(\mathrm{mg} / \mathrm{g})$, and $\mathrm{b}$ is the adsorption equilibrium constant (1/mg).

For the Freundlich equation the linear form is written as:

$$
\log q_{e}=\log K+\frac{1}{n} \log C_{e}
$$

where $\mathrm{k}$ and $\mathrm{n}$ are the constant characteristics of the system.

The best estimated values of all the equation parameters are summarized in Table 2.The adsorption isotherm data are well fitted with both the linearized Langmuir and Freundlich equations and give $\mathrm{R}^{2}=0.931-0.958$ as shown in Figures 4 and 5. The maximum adsorption of Saudi activated clay equals to $47.62 \mathrm{mg} / \mathrm{g}$.

Table 2: $\quad$ The Langmuir and Freundlich equation parameters predicted from adsorption isotherm data of nickel ions onto Saudi activated bentonite at $\mathrm{pH}=7,25^{\circ} \mathrm{C}$ and initial nickel concentration of $100 \mathrm{ppm}$.

\begin{tabular}{cc}
\hline Isotherm parameters & Value \\
\hline Langmuir & 47.62 \\
$\mathrm{q}_{\max }(\mathrm{mg} / \mathrm{g})$ & 0.03 \\
$\mathrm{~b} \quad(\mathrm{l} / \mathrm{mg})$ & 0.931 \\
$\mathrm{R}^{2}$ & \\
Freundlich & 2.825 \\
$\mathrm{~K}(\mathrm{mg} / \mathrm{g})$ & 1.73 \\
$\mathrm{n}$ & 0.958 \\
$\mathrm{R}^{2}$ & \\
\hline
\end{tabular}

According to Tryball [16], it has been shown using mathematical calculations that $\mathrm{n}$ values of between 1 and 10 for the Freundlich isotherm indicate effective adsorption. 


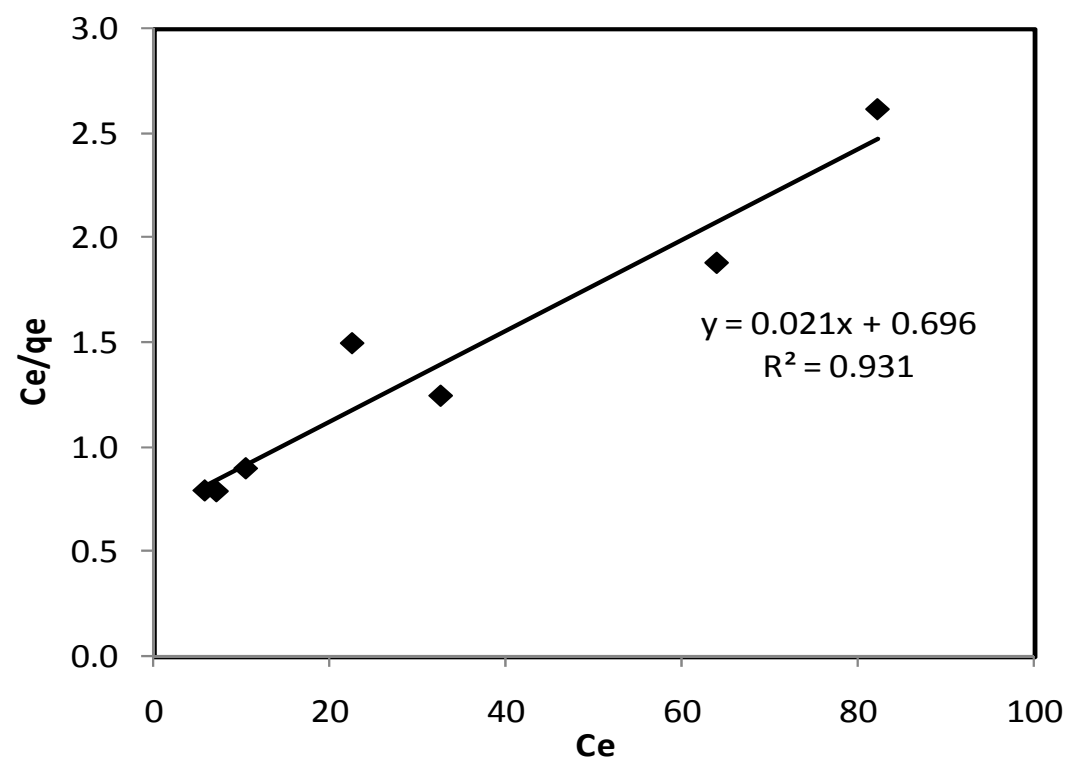

Figure 4: Langmuir plot for the adsorption of nickel on Saudi activated bentonite.

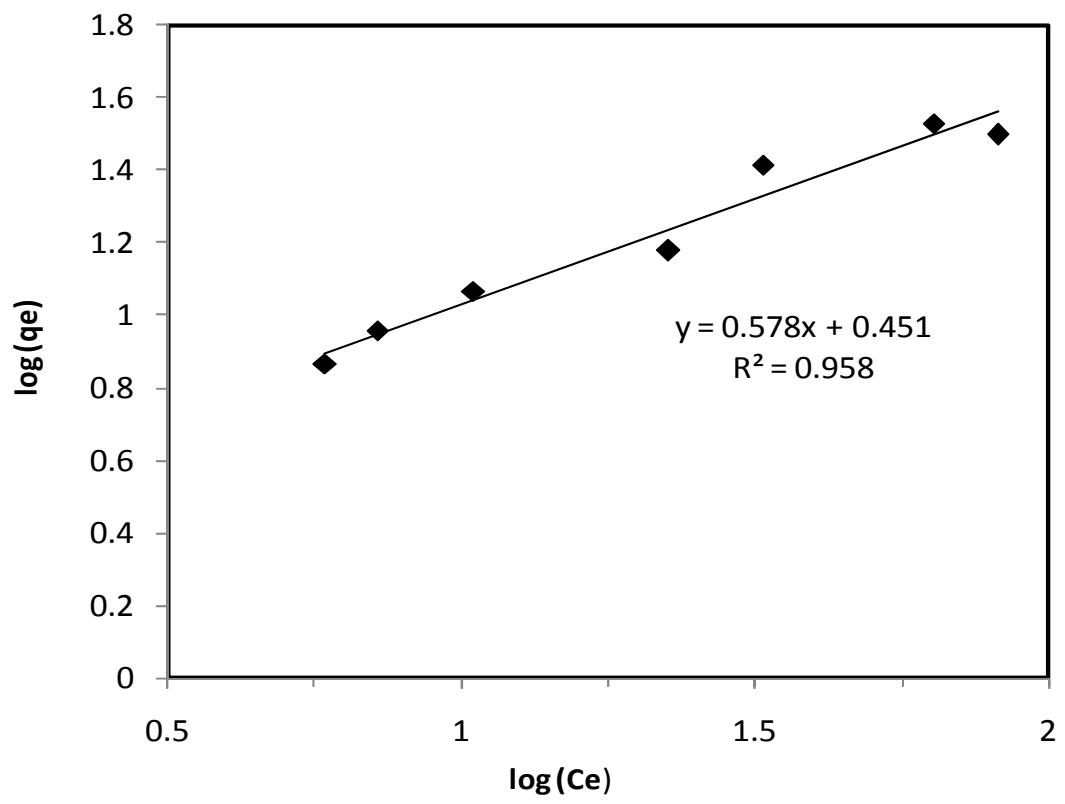

Figure 5: Freundlich plot for the adsorption of nickel on Saudi activated bentonite. 


\subsection{Adsorption kinetic}

The models of adsorption kinetics correlate the solute uptake rate. It is one of the important characteristics defining the efficiency of sorption. The kinetic parameters for the adsorption process were studied on the batch adsorption at room temperature, initial nickel concentration of $50 \mathrm{ppm}$, clay dosage was $0.5 \mathrm{~g}$ and the initial solution $\mathrm{pH}$ was kept unchanged at 3.2. The data were fitted to the first-order Lagergren equation [17],

$$
\left(\log q_{e}-q_{t}\right)=\log q_{e}-\frac{k_{1}}{2.303} t
$$

where $k_{1}\left(\mathrm{~min}^{-1}\right)$ is the first-order rate constant, $\mathrm{q}_{\mathrm{e}}(\mathrm{mg} / \mathrm{g})$ is the amount of adsorbed metal ions on the Saudi bentonite at equilibrium and $\mathrm{q}_{\mathrm{t}}(\mathrm{mg} / \mathrm{g})$ is the amount of nickel adsorbed at time $\mathrm{t}(\mathrm{min})$. The first-order constants can be obtained by plotting $\log \left(\mathrm{q}_{\mathrm{e}}-\mathrm{q}_{\mathrm{t}}\right)$ versus time.

The experimental adsorption kinetics data were analyzed by applying the pseudo-second-order kinetics model, which is expressed as:

$$
\frac{t}{q_{t}}=\frac{1}{k_{2} q_{e}^{2}}+\frac{1}{q_{e}} t
$$

where $k_{2}(\mathrm{~g} /(\mathrm{mg} / \mathrm{min}))$ is the pseudo-second-order kinetics constant, $\mathrm{q}_{\mathrm{e}}(\mathrm{mg} / \mathrm{g})$ is the amount of adsorbed metal ions on the Saudi bentonite at equilibrium and $\mathrm{q}_{\mathrm{t}}$ $(\mathrm{mg} / \mathrm{g}$ ) is the amount of nickel adsorbed at time $\mathrm{t}(\mathrm{min})$. The fit of this model was checked by each linear plot of $\left(t / q_{t}\right)$ versus $t$ as shown in Figure 6.

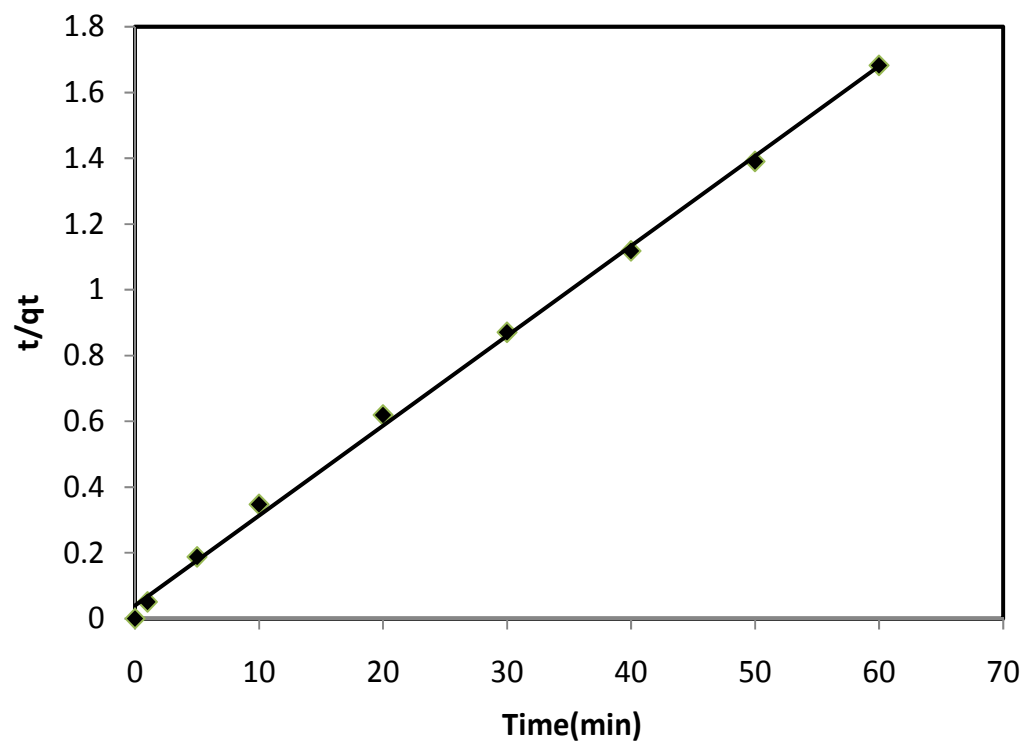

Figure 6: Plot of second order model for nickel adsorption by Saudi activated bentonite. 
By comparing the regression coefficients for each expression a good agreement of the experimental data with the second order kinetic model was observed. The correlation coefficient for the second order kinetic model is 0.999 and the calculated $\mathrm{q}_{\mathrm{e}}$ values agree very well with the experimental data. Thus, a plot of $t / q_{t}$ against $t$ should give a linear relationship with a slope of $1 / q_{e}$. These results agree with same results reported before [18].

\section{Conclusions}

- Saudi natural bentonite samples, which were obtained from khulays deposits, were grinded and sieved to grain size of -200 mesh $(75 \mu \mathrm{m})$. These samples were activated using sulphuric acid to modify there adsorptive property.

- Acid activation was conducted using the optimum operating variables such as, $15 \%$ by weight acid concentration, the temperature of boiling, 90 minutes reaction time, moderate mixing and water to clay ratio of 5:1.

- The sorption of nickel ions on Saudi activated clay was relatively fast and the equilibrium was reached after $40 \mathrm{~min}$. The results show that shaking the mixture of different initial concentration for 40 minutes was sufficient to reach equilibrium. They are also show that increasing the initial nickel concentration decreased nickel removal percentage due to the saturation of clay with nickel ions.

- Removal of nickel ions by Saudi activated bentonite is effected by mixture $\mathrm{pH}$. The adsorption of nickel increases from 70 to $100 \%$ with an increase in solution $\mathrm{pH}$ from 2.0 to 9.0.

- Nickel removal decreases with increasing nickel concentration when nickel concentration increases from 20 to $100 \mathrm{ppm}$.

- The removal of nickel increases as the dose of Saudi activated bentonite increases. This is due to increase in the number of adsorbent sites.

- The adsorption isotherm data were well fitted with both the linearized Langmuir and Freundlich.

- A batch adsorption kinetic experiment revealed that nickel adsorption onto Saudi activated bentonite was well represented by the pseudosecond-order kinetic model. It can be concluded that film diffusion and intraparticle diffusion are simultaneously operating in the whole adsorption process.

- Saudi activated bentonite can be considered as a promising adsorbent for the removal of nickel from aqueous solutions.

\section{Acknowledgements}

The author would like to thank the Deanship of Scientific Research, King Abdulaziz University, for their financial support to accomplish this research. The investigator would like to thank Department of Chemical Engineering staff, King 
Abdulaziz University, for their continual support and invaluable suggestion during this research.

\section{References}

[1] Lin S.H., Lai S.L., Leu H.G. Removal of heavy metals from aqueous solution by chelating resin in a multistage adsorption process. Journal of Hazardous Materials B76, (2000) 139-153.

[2] Kurniawan T.A., Chana G.Y.S., Loa W.-H., Babel S. Physico-chemical treatment techniques for wastewater laden with heavy metals. Chemical Engineering Journal 118 (2006) 83-98.

[3] Denkhaus E., Salnikow K.. Nickel essentiality, toxicity, and carcinogenicity. Critical Reviews in Oncology/Hematology 42 (2002) 35-56.

[4] Garrett R.G. Natural sources of metals to the environment. In: Centeno J.A., Collery P., Fernet G., Finkelman R.B., Gibb H., Etienne J.-C., editors. Metal Ions in Biology and Medicine, vol. 6. Paris: John Libbey Eurotext, 2000:508-10.

[5] Choksia P.M., Joshib V.Y. Adsorption kinetic study for the removal of nickel (II) and aluminum (III) from an aqueous solution by natural adsorbents. Desalination 208 (2007) 216-231.

[6] Carvalho W.A., Vignado C., Fontana J. Ni(II) removal from aqueous effluents by silylated clays. Journal of Hazardous Materials 153 (2008) 1240-1247

[7] Márquez G.E., Ribeiro M.J.P., Ventura J.M., Labrincha J.A. Removal of nickel from aqueous solutions by clay-based beds. Ceramics International 30 (2004) 111-119.

[8] Potgieter J.H., Potgieter-Vermaak S.S., Kalibantonga P.D.. Heavy metals removal from solution by palygorskite clay. Minerals Engineering 19 (2006) 463-470.

[9] Yang S., Li J., Lu Y., Chen Y., Wang X. Sorption of Ni(II) on GMZ bentonite: Effects of $\mathrm{pH}$, ionic strength, foreign ions, humic acid and temperature.

[10] Al-Shahrani, S.S. The feasibility of producing activated clay from a local raw material by sulfuric acid leaching. Msc dissertation, Chemical and Material Engineering Department King Abdulaziz University Jeddah, KSA, 1998.

[11] Chaari I., Fakhfakh E., Chakroun S., Bouzid J., Boujelben N., Feki M., Rocha F., Jamoussi F. Lead removal from aqueous solutions by a Tunisian smectitic clay. Journal of Hazardous Materials, Volume 156, Issues 1-3, 15 August 2008, 545-551

[12] Abollino O., Acetob M., Malandrinoa M., Sarzaninia C., Mentasti E. Adsorption of heavy metals on Na-montmorillonite. Effect of $\mathrm{pH}$ and organic substances, Water Res. 37 (2002) 1619-1627. 
[13] Potgieter J.H., Potgieter-Vermaak S.S., Kalibantonga P.D., Heavy metals removal from solution by palygorskite clay, Miner. Eng. 19 (2006) 463-470.

[14] Langmuir L. The adsorption of gases, mica and platinum. J Am Chem Soc 1918;40:1361.

[15] Freundlich H. Colloid and capillary chemistry. London: Metheun, 1926, p. 883.

[16] Tryball, R.E., 1980. Mass Transfers Operations, third ed. McGraw, New York.

[17] Lagergren S. About the theory of so-called adsorption of soluble substances. Kungliga Svenska Vetenskapsakademiens. Handlingar, Band 1898;24:1-39.

[18] Mishra P.C., Patel R.K. Removal of lead and zinc ions from water by low cost adsorbents. Journal of Hazardous Materials 168 (2009) 319-325. 